\title{
Two Boraginaceae new to the portuguese flora
}

\section{André Carapeto}

Sociedade Portuguesa de Botânica. Travessa do Jardim n. ${ }^{\circ 3}$ 2615-018 A-dos-Potes, Alverca, Portugal.

\section{Correspondencia}

A. Carapeto

e-mail: carapeto@hotmail.com

Recibido: 27 marzo 2018

Aceptado: 2 septiembre 2018

Publicado on-line: noviembre 2018
Dos Boraginaceae nuevas para la flora portuguesa

Key words. Boraginaceae, Portugal, Anchusa puechii, Alkanna tinctoria.

Palavras chave. Boraginaceae, Portugal, Anchusa puechii, Alkanna tinctoria.
In 2016, during field work, the author observed and collected two species of Boraginaceae previously unknown to the Portuguese vascular flora, according to Sequeira et al. (2011): Anchusa puechii Valdés and Alkanna tinctoria Tausch. These are the first records of these species in Portugal, and so, both species should be added to Portuguese vascular flora.

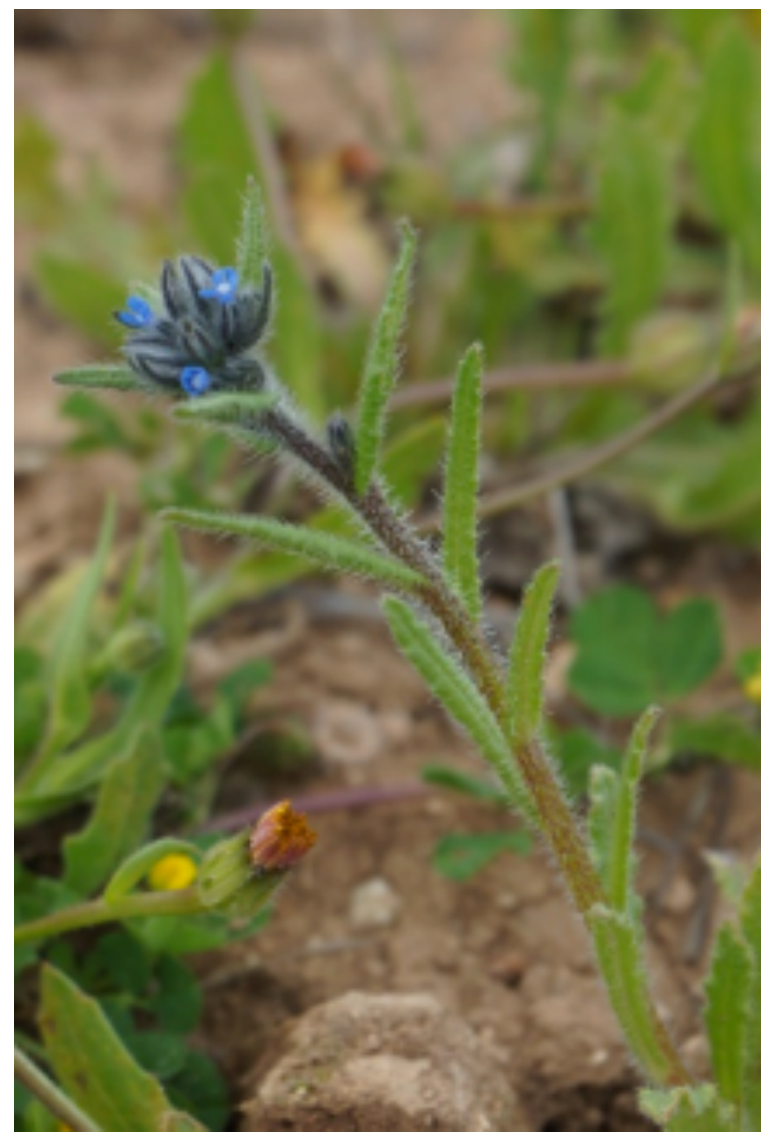

Figure 1. Anchusa puechii Valdés.
Anchusa puechii Valdés (Figura 1).

Portugal, Baixo Alentejo (BAI), Beja, Entre Trigaches e Beringel. UTM 29SNC91: Prados anuais em olival tradicional de sequeiro, em barros castanhos. André Carapeto, 12-04-2016, UEVH 6951.

This plant was considered endemic to Southern Spain, with a distribution range limited to the basins of Guadalquivir and Guadiana rivers (Valdés, 2012a). This plant is now also reported in Portugal, in Baixo Alentejo province, between Trigaches and Beringel (Figure 3). Was observed in annual communities associated with ancient and traditionally managed olive groves, in brown clay basic soils.

The observed population was composed by a small number of individuals $(150-200$, rough estimate), sparsely dispersed in the olive groves. More recently another population was found in Portugal, near Serpa in Baixo Alentejo, occurring in similar habitat conditions (Pereira 2018).

The nearest known population occurs in Spain, near Lobón in Badajoz province, circa $150 \mathrm{~km}$ to NW (Rincón et al. 2008, Anthos, 2018). This plant was assessed as Vulnerable (VU), in Spanish Red List (Moreno coord. 2008). In Portugal, this plant also seems to be seriously threatened, due to the ongoing replacement of ancient olive groves by intensive olive plantations. This replacement, which causes the loss of this species habitat, is taking place in all the surrounding area of the only known location in Portugal. This serious threat was already reported in other species with similar habitat requirements (Pereira et al. 2014).

Alkanna tinctoria (L.) Tausch (Figura 2).

Portugal, Alto Alentejo (AAl), Elvas, Monte do Pombal. UTM 29SPD50: Prado ralo sobre 


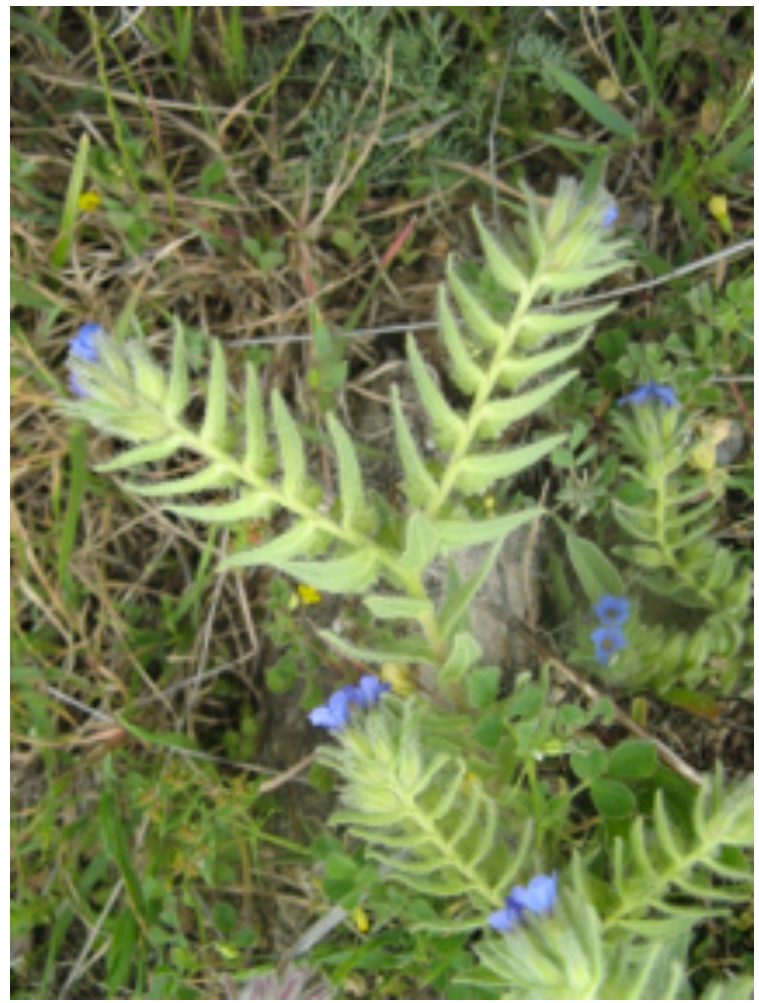

Figure 2. Alkanna tinctoria (L.) Tausch.

substrato básico, pastoreado por ovinos. André Carapeto, 28-03-2016, UEVH 6950.

This plant occurs within a wide range across all Mediterranean basin (Valdés 1987, Valdés 2012b). This plant is now also reported in Portugal, from Alto Alentejo, south of Elvas city, near Monte do Pombal (Figure 3). It was found in thin pastures in basic soils, grazed by ovine cattle and mixed with open shrubland dominated by Retama spherocarpa.

Only 182 individuals were counted, dispersed in three small sites, which occupy a total area inferior to $0,06 \mathrm{~km}^{2}$. All the surveying made in nearby sites, turnout to be unsuccessful.

The nearest known populations occur in Spain, near Cerro Carija (Mérida), in Badajoz province, circa $80 \mathrm{~km}$ to W (Anthos 2018, GBIF 2018). Although is considered a least concern species in Spain (Valdés et al. 2009), in Portugal this species seems to be seriously threatened, since more than half of the only known population is likely to be destructed by a railway development project.

\section{Acknowledgements}

For preparing the herbarium vouchers, the author thanks Carla Pinto Cruz (UEVH - Herbário da Universidade de Évora) and José Manuel Rosa

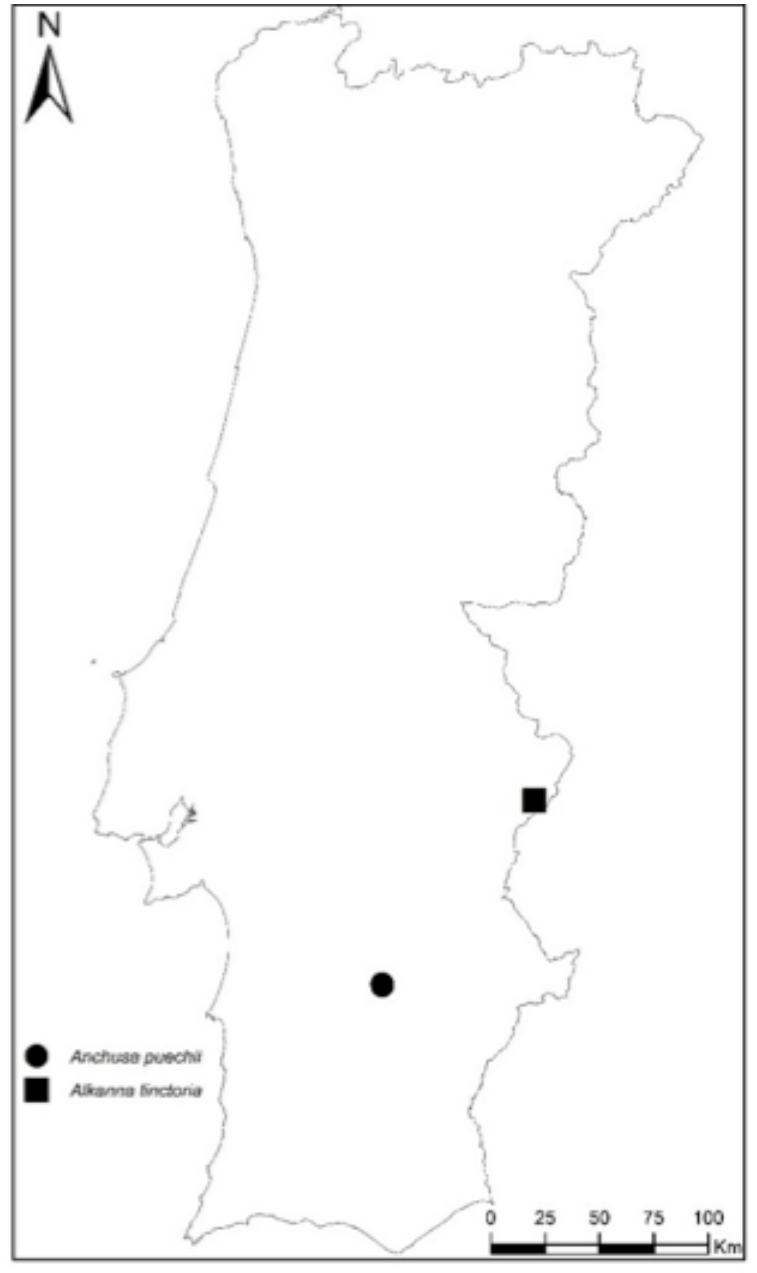

Figure 3. Location of the reported observations.

Pinto (ALGU - Herbário da Universidade do Algarve). Thanks are also due to Ana Júlia Pereira, Miguel Porto (Sociedade Portuguesa de Botânica) and Pedro Arsénio (Instituto Superior de Agronomia).

\section{References}

GBIF.org (2018). Alkanna tinctoria Tausch GBIF Occurrence Download https://doi.org/10.15468/ dl.jn405i Accessed in 22/05/2018

Moreno, J.C., coord. (2008). Lista Roja 2008 de la flora vascular española. Dirección General de Medio Natural y Política Forestal (Ministerio de Medio Ambiente, y Medio Rural y Marino, y Sociedad Española de Biología de la Conservación de Plantas). Madrid. $86 \mathrm{pp}$.

Pereira, A.J. (2018). Anchusa puechii Valdés - mapa de distribuição. Flora-On: Flora de Portugal Interactiva, Sociedade Portuguesa de Botânica. http://www.floraon.pt. Accessed in 22/05/2018

Pereira A.J., Porto, M. \& Gomes, C.T. (2014). Carduncellus cuatrecasasii G. López (Asteraceae) and Eryngium aquifolium Cav. (Apiaceae), two new species to the Portuguese flora. Acta Botanica 
Malacitana, 39: 298- 300

Rincón, S., Vásquez, F.M. \& Ramos, S. (2008). Anotaciones corológicas a la flora en Extremadura 020. Anchusa puechii B. Valdés. Folia Botanica Extremadurensis, vol 2: 90.

Sequeira, M., Espírito-Santo, D., Aguiar, C., Capelo, C. \& Honrado, J.J. (eds.) (2011). Checklist da Flora de Portugal Continental, Açores e Madeira. ALFA

Valdés, B. (2009). Boraginaceae In: G. Blanca, B. Cabezudo, M. Cueto, C. Fernandez Lopez \& C. Morales Torres (eds.), Flora Vascular de Andalucía Oriental Volumen 3: 329-352. Consejeria de Medio Ambiente, Junta de Andalucia, Sevilla.ISBN: 987-8492807-15-4

Valdés, B. (2012a ). Anchusa L. in Talavera, S.; Andrés,
C.; Arista, M.; Fernández Piedra, M.P.; Gallego, M.J.; Ortiz, P.L.; Romero Zarco,C.; Salgueiro, F.J.; Silvestre, S.; \& Quintanar, A. (eds.). 2012. Flora iberica, vol. XI. Gentianaceae-Boraginaceae. Madrid, Real Jardín Botánico CSIC.

Valdés, B. (2012b). Alkanna Tausch. in Talavera, S.; Andrés, C.; Arista, M.; Fernández Piedra, M.P.; Gallego, M.J.; Ortiz, P.L.; Romero Zarco,C.; Salgueiro, F.J.; Silvestre, S.; \& Quintanar, A. (eds.). 2012. Flora iberica, vol. XI. Gentianaceae-Boraginaceae. Madrid, Real Jardín Botánico CSIC.

Valdés, B. (1987). Boraginaceae. In: Valdés B., Talavera S. \& E. Fernández-Galiano (eds.), Flora Vascular de Andalucía Occidental 2: 375-404. KETRES editora, S.A., Barcelona. 